\title{
Modeling and Simulation of Source Separation in Sanitation Systems for Reducing Emissions of Antimicrobial Resistances
}

\author{
Jörg Londong *, Marcus Barth and Heinrich Söbke \\ Bauhaus-Institute for Infrastructure Solutions (b.is), Bauhaus-Universität Weimar, Goetheplatz 7/8, \\ 99423 Weimar, Germany; marcus.barth@uni-weimar.de (M.B.); heinrich.soebke@uni-weimar.de (H.S.) \\ * Correspondence: joerg.londong@uni-weimar.de
}

check for updates

Citation: Londong, J.; Barth, M.; Söbke, H. Modeling and Simulation of Source Separation in Sanitation Systems for Reducing Emissions of Antimicrobial Resistances. Water 2021, 13, 3342. https://doi.org/ $10.3390 /$ w13233342

Academic Editor: Qilin Wang

Received: 25 October 2021

Accepted: 22 November 2021

Published: 25 November 2021

Publisher's Note: MDPI stays neutral with regard to jurisdictional claims in published maps and institutional affiliations.

Copyright: (c) 2021 by the authors. Licensee MDPI, Basel, Switzerland. This article is an open access article distributed under the terms and conditions of the Creative Commons Attribution (CC BY) license (https:/ / creativecommons.org/licenses/by/ $4.0 /)$.

\begin{abstract}
Antimicrobial resistance (AMR) is identified by the World Health Organization (WHO) as one of the top ten threats to public health worldwide. In addition to public health, AMR also poses a major threat to food security and economic development. Current sanitation systems contribute to the emergence and spread of AMR and lack effective AMR mitigation measures. This study assesses source separation of blackwater as a mitigation measure against AMR. A source-separation-modified combined sanitation system with separate collection of blackwater and graywater is conceptually described. Measures taken at the source, such as the separate collection and discharge of material flows, were not considered so far on a load balance basis, i.e., they have not yet been evaluated for their effectiveness. The sanitation system described is compared with a combined system and a separate system regarding AMR emissions by means of simulation. AMR is represented in the simulation model by one proxy parameter each for antibiotics (sulfamethoxazole), antibiotic-resistant bacteria (extended-spectrum beta-lactamase E. Coli), and antibiotic resistance genes (blaTEM). The simulation results suggest that the source-separation-based sanitation system reduces emissions of antibiotic-resistant bacteria and antibiotic resistance genes into the aquatic environment by more than six logarithm steps compared to combined systems. Sulfamethoxazole emissions can be reduced by $75.5 \%$ by keeping blackwater separate from graywater and treating it sufficiently. In summary, sanitation systems incorporating source separation are, to date, among the most effective means of preventing the emission of AMR into the aquatic environment.
\end{abstract}

Keywords: microbial resistances; antimicrobial resistance genes; source separation; resource-oriented sanitation; UASB; SAmpSONS

\section{Introduction}

Antimicrobial resistance (AMR) is one of the greatest threats to global health, food security, and development to date. The World Health Organization (WHO) has identified AMR as one of the top 10 threats to public health worldwide [1]. A major cause of AMR is the high use of antibiotics in both human and veterinary medicine and their subsequent emission into the environment [2]. Bush et al. [3] specified high population densities, a lack of drinking water supply, and the inadequate purification of wastewater as further causes. Berendonk et al. [4] attributed the growing spread of AMR essentially to three effects that also co-occur: the horizontal gene transfer of antibiotic resistance genes (ARGs), genetic mutations, and the selection pressure triggered by antibiotics or other pollutants, which ultimately leads to antibiotic-resistant bacteria (ARB). The high hazard potential of AMR is also due to the development of new antibiotics being slower than the build-up of resistance to antibiotics, so treatment options are reduced $[5,6]$. The consequences of spreading AMR are increased incidence of disease and mortality in both infected humans and animals [4].

Frequently, the economic losses due to AMR are presented to illustrate the enormous impact of AMR [1,7]. Ignoring any other potentially significant effects, Taylor et al. [7] considered solely the costs arising from increased mortality and increased susceptibility to 
disease in a reduced labor force available to a society. Taylor et al. forecasted an annual decrease in the gross national product of $0.14 \%$ worldwide due to AMR over a period of 40 years, even though the current level of AMR did not increase. This decrease corresponds to 453 billion United States dollars (USD) annually (cumulatively over 40 years: 5.8 trillion USD). The labor force will be reduced by 14 million workers per year over 40 years. The figures assume a rather optimistic scenario of constant resistance rates; in the pessimistic scenario of absolute resistance, 444 million fewer workers will be available each year after 40 years. This analysis is very rationally oriented, and is not even a fully comprehensive analysis, as it neglects the emotional and ethical aspects of death and disease. However, the analysis shows the hazardous potential of AMR extremely acutely. Although, strictly speaking, microbes include not only bacteria, but also other microorganisms, such as fungi or various algae, AMR is simplistically characterized by the amounts of ARB, ARGs, and antibiotics (ABs) [8].

\subsection{Significance of the Aquatic Environment for the Dissemination of AMR}

Although AMR may arise in other environments as well, the aquatic environment is of particular importance for the spread of AMR, as it is a conducive environment for the above-mentioned effects of AMR [3]. For example, low concentrations of ABs are also considered conducive to selection pressure [9] and as stimulants for horizontal gene transfer [10]. Thus, ARBs are found particularly in lakes and rivers with wastewater discharges or agricultural use in the catchment area [11,12]. To reduce the spread of AMR, the input of AMR-causing substances into water bodies must be lowered. One of the starting points for reducing inputs is urban drainage.

\subsection{Input Paths in Urban Drainage}

Pinnekamp et al. [13] systematically described the input paths of AMR for urban drainage (Figure 1). The material flows of urban drainage containing feces are particularly relevant. Together with feces, humans also excrete therapeutically administered ABs. Accordingly, ARG and ARB are also discharged into wastewater via feces.

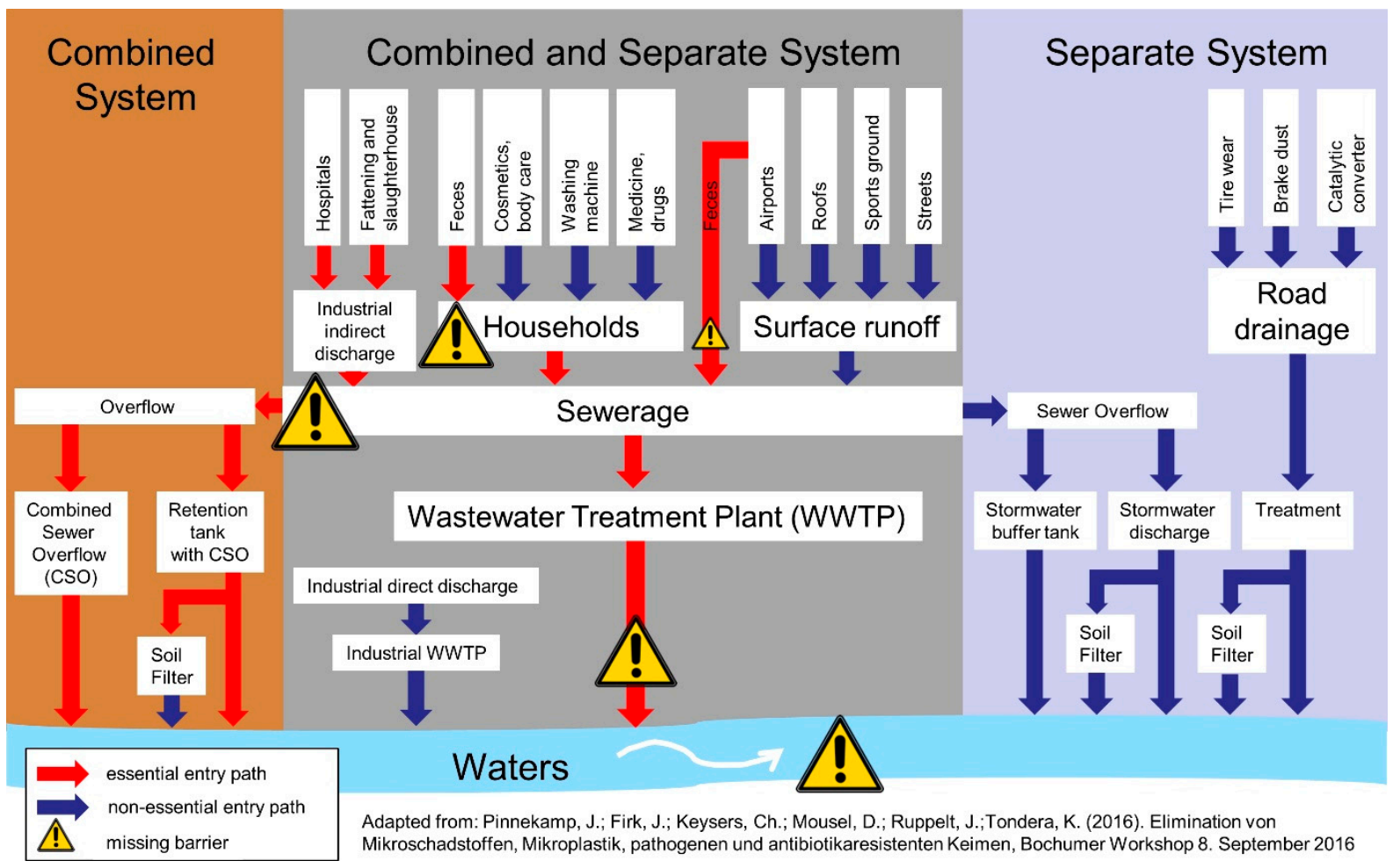

Figure 1. Relevant emission paths of antimicrobial resistances (adapted from [13]). 
The primary sources of AMR are assumed to be feces from households, from means of transport, such as airplanes and trains, from hospitals, and from animal production facilities and slaughterhouses. All of these sources discharge wastewater into the urban sewerage, which drains it to wastewater treatment plants (WWTPs). WWTPs, which are considered a reservoir for AMR [14], discharge the wastewater back into the water body-purified but not free of ARB and ARGs.

Hospitals, as sites of administering of antibiotics, seem to be an obvious source of AMR. However, the literature reports that AMR detected in wastewater is not exclusive to hospital sources and that hospitals are not the main sources of AMR load, as the flow is comparably low (Ref. [15] cited in [16,17]).

According to Pinnekamp et al. [17], who modeled a fictitious settlement area that was drained using a combined system, the WWTP effluent is the relevant emission pathway for AMR. In combined systems, the combined sewer overflows (CSOs) make the largest contribution to the emissions of ARGs and ARB.

Combined systems are drainage systems in which both wastewater and stormwater are discharged via one sewer system [18]. Over 50\% of German urban drainage systems are combined systems [19]. It is estimated that $70 \%$ of the sewers in Europe belong to combined systems [20]. If the inflow to WWTPs exceeds the WWTPs' capacities, CSOs occur: Parts of the combined wastewater are discharged-untreated-into surface waters before reaching the WWTPs [21]. Due to climate change, the frequency of CSOs is expected to increase further [20].

The pollution of water bodies by wastewater constituents discharged into surface waters in combined systems is currently being critically debated anew [20,22-25]. The debate rarely differentiates between specific constituents. It has been known for some years that anthropogenic micropollutants and microplastics have been detected in addition to classic oxygen-depleting pollutants [20,21,25-34]. Furthermore, AMRs are also mentioned as constituents discharged into surface waters from combined systems $[20,35,36]$.

\subsection{Reduction of AMR Emissions into the Aquatic Environment}

In the literature, various measures for reducing AMR emissions into the aquatic environment have been discussed [37-41]. The measures were divided by Firk et al. [8] into advanced process technologies at WWTPs, decentralized treatment of particularly polluted wastewater, and measures for reducing emissions from CSOs. The advanced process technologies for wastewater treatment, ultrafiltration, ultraviolet (UV) treatment, ozonation, and the adsorption with activated carbon, as well as their combination, were proposed as the fourth treatment stage [42]. Decentralized treatment of particularly polluted wastewater includes the separate treatment of hospital wastewater. To achieve the reduction of emissions from CSOs, on the one hand, the treatment of CSOs was proposed, such as by using retention soil filters, and on the other, the reduction of CSOs was mentioned. A reduction of CSOs is achieved through specific measures, such as integral flow control, increasing retention areas in the sewer network, or increasing the possible combined sewer inflow to WWTPs. Overall, Firk et al. [8] concluded that only a combination of different measures might significantly reduce the emissions and that measures to be taken at the source might be useful. However, measures taken at the source, such as the separate collection and discharge of material flows, were not considered so far on a load balance basis, i.e., they have not yet been evaluated for their effectiveness. Thus, to our knowledge, this is the first study to examine the effectiveness of separate collection and discharge of material flows to contribute to the reduction of AMR emissions into the aquatic environment. The rest of the article is organized as follows: The next section describes the option proposed, the three sanitation systems, and SAmpSONS, which is the simulation software used. Section 3 contains the data used in the simulation, the site under investigation that was used to compare the three sanitation systems, and the results of the simulation. Section 4 discusses the techno-economic challenges of transforming combined systems into the proposed 
resource-separation-modified combined systems. Finally, the results are discussed, and the conclusions are drawn.

\section{Materials and Methods}

\subsection{Proposed Option}

Separate collection and (centralized) treatment of specific loaded sub-streams (feces) have not yet been considered in the literature as a measure for reducing AMR emissions but should be investigated as an option. Londong [43] proposed a new long-term strategy for transforming combined systems into a "source-separation-modified combined system" incorporating stormwater detachment, stormwater management, blackwater separation, and its separate treatment. Using the SAmpSONS simulation software [44,45], the effectiveness of this option in reducing AMR emissions is demonstrated (Figure 2).

Research Question

What is the impact of source separation-modified combined systems on the emission of AMR into the aquatic environment?

Methodology: Selection of

\begin{tabular}{l}
\hline Variant \\
Sanitation System \\
$\begin{array}{l}\text { Variants } \\
\text { - Combined System } \\
\text { - Separate System } \\
\text { Source Separation- } \\
\text { modified Combined } \\
\text { Syslem }\end{array}$
\end{tabular}

Results

Source separation-modified combined systems are a highly effective means for reducing AMR emissions: Antibiotic-resistant bacteria and antibiotic resistance genes are reduced by six log steps.

Figure 2. Study design.

\subsection{Sanitation Systems under Comparison}

Based on two conventional sanitation systems-the combined system and the separate system-we consider a system variant that has not been investigated so far: the sourceseparation-modified combined system. In the following, each of these systems is described.

\subsubsection{Combined System}

In a combined system, wastewater and stormwater are discharged together to the WWTP. In combined systems, firstly, AMRs are released into the aquatic environment via CSOs and, secondly, regarding the WWTP-treated fraction, are not completely removed from the wastewater, so AMRs are discharged with the treated water into the surface water.

\subsubsection{Separate System}

A characteristic of a separate system is the separate collection and discharge of stormwater and wastewater. The wastewater is discharged to WWTPs, where the wastewater is treated. The stormwater is discharged into surface waters or infiltrated. If infiltration takes place using vegetated soil layers or discharge into surface waters is done via retention soil filters, the stormwater is considered treated. For the sake of this study, it is assumed that the water discharged into surface waters in the separate system is largely free of pollution from feces, i.e., there are no misconnections, and thus no significant AMR loads are to be expected. The treated wastewater thus remains as the input path of AMRs into the aquatic environment in a separate system. 


\subsubsection{Source-Separation System}

The basic principle of source-separation systems is the separate collection (also called no-mix), discharge, and treatment of source streams, such as blackwater (urine, feces, and flush water), graywater, and stormwater. The energy and resources, as well as the environmental potentials, of source separation have been frequently described in recent years [46-49]. With respect to AMR, it is pertinent to note that blackwater contains approximately $50 \%$ of the chemical oxygen demand (COD) load, nitrogen, and phosphorus, as well as nearly $100 \%$ of ABs, ARB, and ARGs [8,49]. Furthermore, it must be considered that the share of blackwater in the total wastewater is low, but the respective share in the pollutant load is substantial.

As part of the separate collection of blackwater, vacuum toilets further reduce the volume flow of blackwater [50,51]. Separate discharge of blackwater and graywater typically requires separate discharge piping systems in buildings, which are currently not the standard equipment in buildings. Separate discharge piping systems are easy to install in newly constructed buildings. Among the more cost-effective options for providing separate discharge of blackwater and graywater in existing buildings is double inliner technology [52-54]. A sensor-controlled wastewater switch that allows the separation of blackwater and graywater in a two-chamber inspection shaft outside the building does not require any structural intervention in the building itself $[55,56]$.

Accordingly, the source-separation-modified combined system whose transformation from a combined system is proposed in this article provides for blackwater to be drained separately via vacuum system, for stormwater to be as locally discharged as possible or discharged via a newly constructed stormwater sewer, and for the combined sewers to be used to discharge the graywater (Figure 3). The existing WWTPs are to be used for graywater treatment and are to be extended with a blackwater treatment system. The blackwater treatment (Figure 4) is based on an upflow anaerobic sludge blanket digestion (UASB) reactor. Dewatered digestate is incinerated, while the liquid phase is subjected to phosphorus precipitation, deammonification or ammonia stripping, and thermal disinfection.

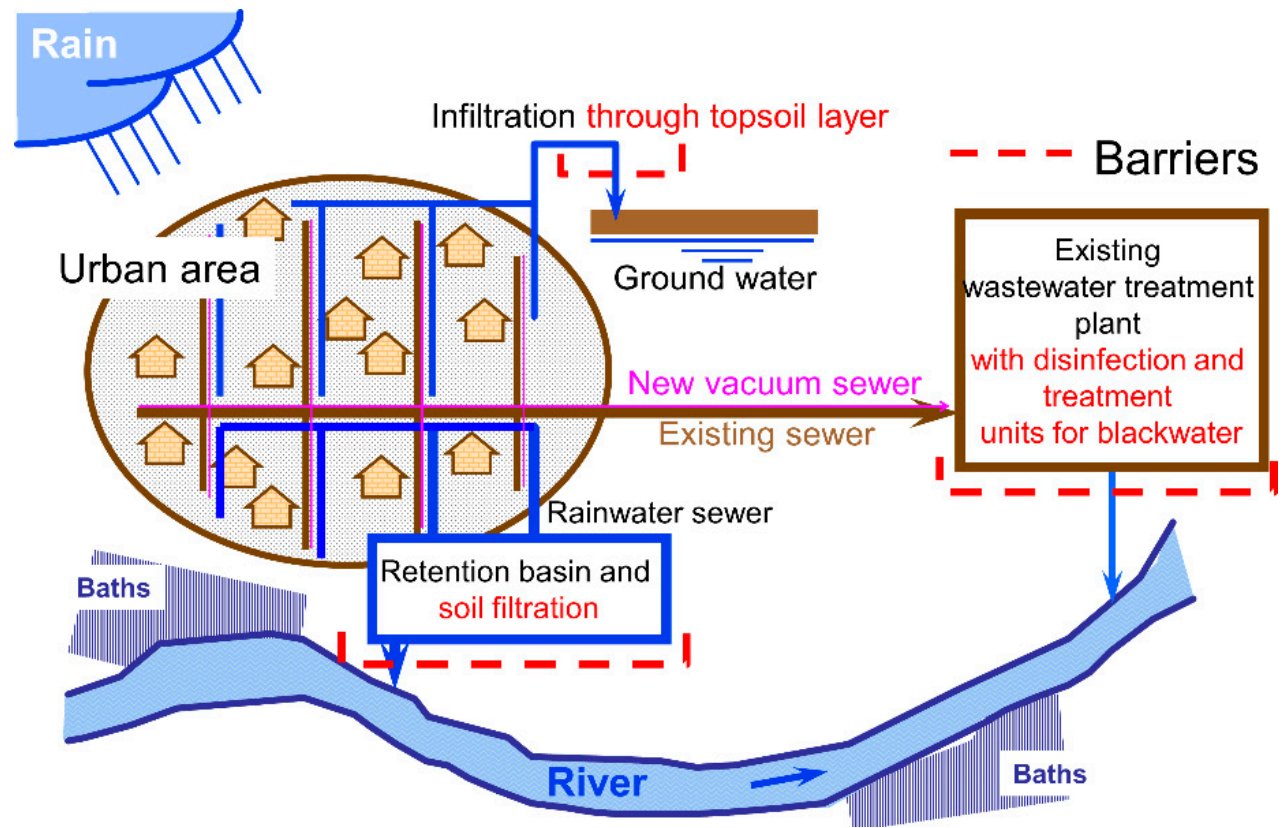

Figure 3. Source-separation-modified combined system (adapted from [57]). 


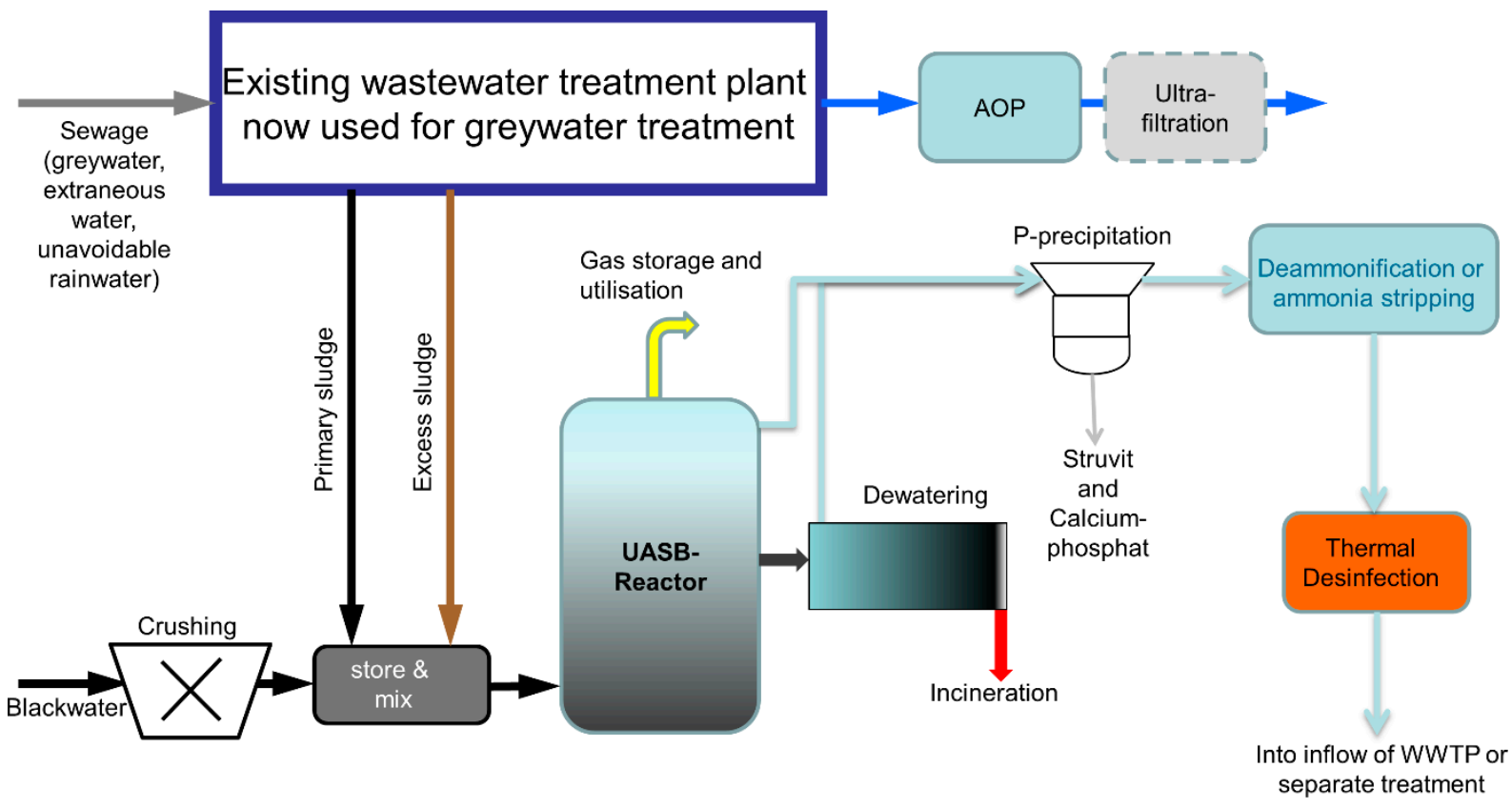

Figure 4. Proposed blackwater treatment at WWTPs (adapted from [43]).

\subsection{SAmpSONS Simulation Software}

SAmpSONS [58] is a free software for static simulation and assessment of the sustainability of sanitation systems $[44,45]$. SAmpSONS was chosen for the simulation in this study due to its high versatility combined with its straightforward usability, which provides easy-to-understand models. The sanitation systems to be evaluated are modeled modularly from so-called components, such as WWTPs, sewer systems, or sub-surface drainage. The components are subjected to material flows, such as wastewater or graywater. The material flows are characterized by concentrations of a defined set of constituents, such as COD or diclofenac as a micropollutant. For each component, values are specified for the removal rates with respect to the defined set of constituents. All defined values are to be seen as default values; they can be overwritten at any time depending on the model. The fate of the material flows is visualized by using Sankey diagrams. The sustainability assessment is based on parameters of each component in addition to the material flows. SAmpSONS offers the possibility of defining three constituents in a model-specific way. This option was used for the study presented here, and a proxy for each of the categories-ABs, ARB, and ARGs-was integrated into the simulation models. The choices required to build a simulation model are summarized in Table 1.

Table 1. Simulation model choices in SAmpSONS.

\begin{tabular}{|c|c|}
\hline Choice & Description \\
\hline Site Under Investigation (SUI) & $\begin{array}{c}\text { A study area for which a sanitation system is to be assessed must be chosen. } \\
\text { The SUI specifies, among other things, the quantity and type of persons or } \\
\text { dischargers. }\end{array}$ \\
\hline Sanitation System & $\begin{array}{l}\text { A sanitation system is described by components, each of which is provided by } \\
\text { SAmpSONS. }\end{array}$ \\
\hline Material Flows & $\begin{array}{l}\text { The material flows assessed result from the sanitation system chosen or from } \\
\text { the respective components of the sanitation system. The material flows are } \\
\text { predefined by SAmpSONS. }\end{array}$ \\
\hline Constituents & $\begin{array}{l}\text { SAmpSONS features a set of constituents that are considered for all material } \\
\text { flows. Three constituents are freely definable. }\end{array}$ \\
\hline Removal Rates & $\begin{array}{l}\text { For all components, removal rates are to be defined with respect to each } \\
\text { constituent. The predefined standard values may also be used unchanged. }\end{array}$ \\
\hline
\end{tabular}




\section{Results}

\subsection{Input Data}

\subsubsection{General Considerations}

The model area from the German Association for Water, Wastewater, and Waste (DWA) standard A 102 [59] was selected as a practically relevant site under investigation (SUI) (Figure 5), as it is often used in the technical discourse [22]. The source-separation-modified combined system presented in Section 2.2.3 was modeled for this SUI, which is described in Table 2. For comparison, the sanitation system originally described in the standard A 102 , consisting of combined and separate systems, was also modeled in SAmpSONS.

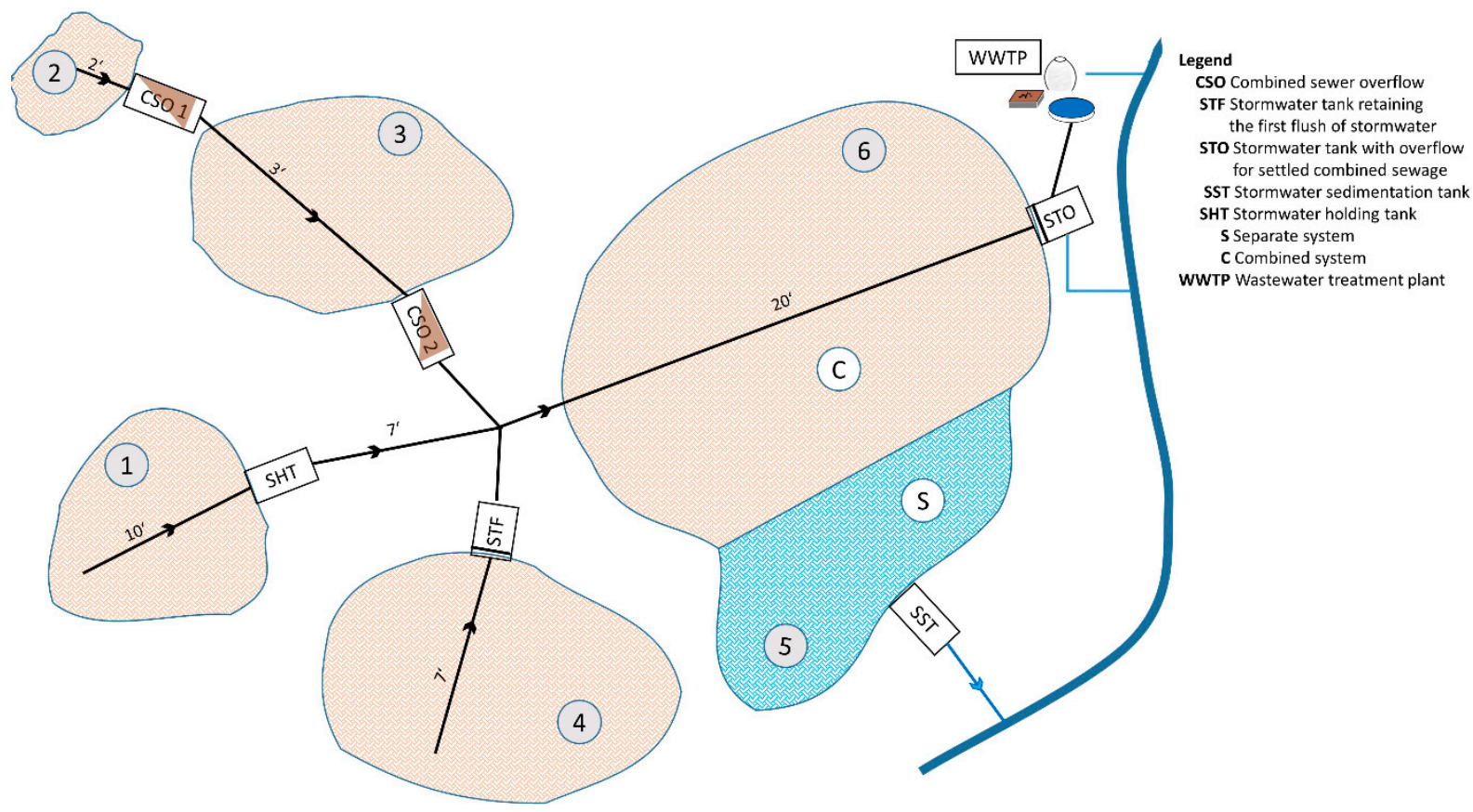

Figure 5. Schematic representation of the sanitation system with subareas 1 to 6 and structures (adapted from [60]).

Table 2. Characteristics of the site under investigation [59].

\begin{tabular}{ccccccccc}
\hline & & Subarea 1 & Subarea 2 & Subarea 3 & Subarea 4 & Subarea 5 & Subarea 6 \\
\hline Population & $\mathrm{P}$ & 3200 & 970 & 600 & 1900 & 1100 & 8200 \\
\hline Wastewater & $\mathrm{L} / \mathrm{s}$ & 4.8 & 1.1 & 0.9 & 2.9 & 1.5 & 12.4 \\
\hline & $\mathrm{m}^{3} / \mathrm{d}$ & 414.72 & 95.04 & 77.76 & 250.56 & 29.60 & 1071.36 \\
\hline $\begin{array}{c}\text { Stormwater and } \\
\text { extraneous water }\end{array}$ & $\mathrm{L} / \mathrm{s}$ & 4.8 & 1.1 & 0.9 & 2.9 & 1.5 & 12.4 \\
\hline & $\mathrm{m}^{3} / \mathrm{d}$ & 414.72 & 95.04 & 77.76 & 250.56 & 129.60 & 1071.36 \\
\hline
\end{tabular}

The population-specific loads for ARB and ARGs required for the simulation could not be identified in the literature. For this reason, data provided by Julian Firk [61] based on the results of the research project HyReKa [62] were used. The values were calculated from daily loads in the inflow of WWTPs during dry weather and were back-calculated to the connected population equivalents. The daily loads were determined by $24 \mathrm{~h}$ composite samples at 10 WWTPs without industrial influents.

\subsubsection{Selection of Constituents}

In the following, the constituents used to serve as proxies in the simulation for each category (ABs, ARGs, and ARB) are described. 
Antibiotics (ABs). Sulfamethoxazole is one of the more frequently investigated pharmaceutical residues in WWTPs and, for the group of antibiotics, has the most entries in the data compilation for loads, removal rates, and concentrations in WWTP influents and effluents. Therefore, the constituent is suitable to be used as a proxy for antibiotics. Based on values collected for population-specific loads $[8,63,64]$, a population-specific load of $0.1 \mathrm{mg} /(\mathrm{Pxd})$ was assumed for sulfamethoxazole. Idealized, it is assumed in the following that there is no mis-disposal via sinks and washbasins, and thus, there is no entry of antibiotics into the graywater. The input of sulfamethoxazole into wastewater is completely assigned to the sub-stream of urine (Ref. [65] cited in [66]).

Antibiotic-Resistant Bacteria (ARB). Extended-spectrum-Betalactamase E. Coli (ESBLE.Coli) was chosen as the representative for ARB. ESBL-E.Coli is a special subgroup of the gram-negative escherichia coli from the enterobacteriaceae family. In general, E. Coli is one of the most important indicator bacteria in urban drainage [64]. The ESBL-E.Coli selected here were E. Coli strains capable of producing B-lactamases that render a variety of different antibiotics ineffective. Because of the high medical relevance of ESBL strains and the decent data base for normal E. Coli strains, ESBL-E.Coli is particularly well-suited as an indicator for assessing the spread of resistant bacterial strains through sanitation systems. For ESBL-E.Coli, $10^{8.24}$ colony forming units (CFU)/(Pxd) were taken as the median of 75 measurements [61].

Antibiotic Resistance Genes (ARGs). Common ARGs include blaTEM, ermB, tetM, and sul1, which together account for $99.8 \%$ to $99.9 \%$ of the total gene input [67]. ARGs detected with moderate frequency in WWTP effluents include the beta-lactam-resistance genes blaCMY2, blaCTX-M15, blaCTX-M32, and the inherited gene for carbapenem resistance, blaOXA48. Only rarely detected were blaNDM-1, vanA, mecA, and mcr-1, which encode resistance to reserve antibiotics [67]. Clinically relevant resistances, such as vanA and ermB, are mainly detected in wastewater from residential areas affected by hospitals $[67,68]$.

blaTEM was chosen as a proxy for ARGs. The blaTEM resistance gene is a resistance gene encoded on the resistance plasmid that enables bacteria to produce $\beta$-lactamases. This resistance gene is among the most frequent resistance genes found in wastewater [67]. This gene was selected primarily because values for population-specific load and removal rates-albeit low-were available. For blaTEM, $10^{8.05}$ cell equivalents $/(\mathrm{P} \times \mathrm{d})$ were taken as the median of 57 measurements [61].

\subsubsection{Material Flows}

Wastewater was classified into the material flows of blackwater (urine, feces, and flush water), graywater, and stormwater. Since SAmpSONS offers the possibility of adjusting the wastewater characteristics, not only information on the amount excreted for a constituent is required, but also information on whether the constituent enters the wastewater via the urine (renal excretion) or the feces (biliary excretion). For this purpose, data from the literature on excretion rates for various constituents were collected and, if applicable, assigned to the urine or feces sub-stream.

\subsection{Removal Rates of the Treatment Stages \\ 3.2.1. General Considerations}

Research into the behavior of AMR in conventional wastewater treatment is not yet very advanced. The amount and quality of data from the literature on removal rates for $\mathrm{ABs}, \mathrm{ARB}$, and ARGs vary considerably, and measurement series are only comparable to a limited degree. Especially for ARGs, only a small amount of data are available for both wastewater treatment and anaerobic digestion. Even more than for $\mathrm{AB}$, the comparability of results is hampered by the large number of different genes alone, since the same types of ARGs have rarely been investigated under comparable conditions.

From the literature, it appears that the determination of the removal rates of the respective WWTPs is usually based on comparisons of the concentrations in WWTP influents and effluents. This approach is problematic because it does not provide any information on 
whether a contaminant was actually removed or only a redistribution from the effluent to the sludge occurred [69]. High treatment effectiveness in regard to effluent concentrations does not necessarily mean high total overall removal rates [70].

\subsubsection{Activated Sludge Process as Aerobic Treatment}

For wastewater treatment, the activated sludge process (ASP) is widely used. Thus, removal rates of the ASP with respect to the constituents representing AMR need to be determined.

ABs. The removal rates found for ABs are substance-specific and process-specific. The fluoroquinolone group of active substances, for example, tends to adsorb to sludge [68,71,72] and is described as only moderately biodegradable [64]. Thus, this active substance is likely not to be degraded by the ASP, but only shifted from the liquid to the solid phase. The active substance sulfamethoxazole, on the other hand, has a very low sorption affinity $[64,72,73]$, which suggests that the removal rate is predominantly achieved through biodegradation.

The data for the simulation were obtained from the literature on removal rates in conventional WWTPs for the active substances selected. Where statements were available on the more precise behavior, i.e., on whether the substance was removed from the wastewater through biodegradation or sorption, a corresponding breakdown of removal rates was made.

The overall removal rate of conventional WWTPs for sulfamethoxazole is generally in the range of $30 \%$ to $70 \%$, with the majority of the removal rate being achieved by biodegradation of the active substance, albeit only moderately [8,63,64,66,70,74-77] (Ref. [66] cited in [78]). For the simulation, it was therefore assumed that $50 \%$ of sulfamethoxazole was biodegraded. Conservatively, it was assumed that $5 \%$ of the load adsorbed to the sludge, resulting in $45 \%$ remaining in the effluent of the WWTP.

ARB. Regarding the removal rate for $A R B$, it is stated that wastewater treatment reduces the load of indicator organisms, such as E. coli and enterococci, by up to three logarithm steps, while a relative removal of the resistant fraction of ARB and ARGs is not achieved to the same extent [79]. Removal rates of over $99 \%$ [8,39,64,80-82] initially suggest that only a small fraction of ARB load is discharged to surface water via the WWTP effluent. However, this impression is deceptive due to the high concentrations, for example, from $107 \mathrm{CFU} / 100 \mathrm{~mL}, 105 \mathrm{CFU} / 100 \mathrm{~mL}$, which still remain at a treatment efficiency of 99\%. As a result, conventional WWTPs emit large amounts of ARB into the aquatic environment and contribute significantly to the spread of AMR $[64,67,83]$.

The data on the sorption characteristics of the bacterial strains required for the simulation could not be determined from the research in the literature. In the following, based on the assessment of Mascher et al. [82], it is therefore assumed that the bacteria are not deadened. Hence, the assumed removal rate for ESBL-E.Coli of $99.5 \%$ is fully attributed to sorption to the sludge. The remaining $0.5 \%$ of the ARB load is passed to the effluent of WWTPs.

ARGs. Some of the ARGs found in wastewater may be removed by conventional WWTPs. However, as for bacteria, complete retention of the total gene load is not possible [68]. The consideration of ARGs in WWTPs and in wastewater has not been carried out for very long, which explains the availability of measurements in the literature to an even smaller extent than for ABs or ARB (cf. Table 3). However, it is also apparent that removal rates for various resistance genes vary significantly. The literature does not provide any information on whether these genes are degraded or whether the removal rate is achieved through sorption. The conditions prevailing in the aeration basins do not suggest deoxyribonucleic acid being degraded. Thus, it is assumed in the following that the characteristics of ARGs correspond to those of ARB. For this reason, the removal rates are achieved through sorption to the sludge alone. For blaTEM, a removal rate of $99.5 \%$ (corresponding to 2.5 logarithm steps) is established by sorption to the sludge. The remaining $0.5 \%$ is discharged into the effluent of the WWTPs. To be noted is that sludge is not only a reservoir for ARB, but also for ARGs [84]. 
Table 3. Removal rates in conventional wastewater treatment plants for blaTEM.

\begin{tabular}{ccccc}
\hline Removal Rates & Fraction into Sludge & Fraction into Effluent & Remark & Literature \\
\hline $1.03 \log 10 \mathrm{CFU} / 100 \mathrm{~mL}$ & unclear & rest & Median values, high & [41] \\
$2.6 \operatorname{logarithm}$ steps & unclear & rest & variation & {$[8]$} \\
2.6 logarithm steps & unclear & rest & {$[39]$} \\
2.44 logarithm steps & unclear & rest & {$[85]$} \\
\hline
\end{tabular}

\subsubsection{Anaerobic Treatment of Blackwater}

Knowledge about the contribution of the anaerobic treatment of sludge and other digestate substrates to the spread of AMR has also been limited so far. Thus, for ABs and ARGs, there are only a few references describing the influence of anaerobic digestion on the fate of these constituents in the substrate. Predominantly, these studies have been conducted on a laboratory scale. Table 4 describes the values applied in the simulations of this study.

ABs. The removal rate for ABs depends on the biodegradability of the active substance. In a series of laboratory-scale experiments, decent degradation performance for most antibiotic compound groups within UASB reactors was found [86]. Substrate-specific differences in removal rates were also noted for most antibiotic drug groups in the same study [86]. The active substance sulfamethoxazole is removed from wastewater through biodegradation processes, whereas active ingredients from the quinolone group are primarily removed through sorption to the solid phase. Hou et al. [86] reported a removal rate of approximately $75 \%$ for sulfamethoxazole. This removal rate was in the expected range between the ASP removal rate (see Section 3.2.2) and the data from the literature on anaerobic digestion of $90 \%$ to $99 \%$ [71,87]. Therefore, for the simulation, a removal rate of $75 \%$ is assumed for anaerobic digestion and sulfamethoxazole.

It should be noted that the concentrations of the active substance in the digestion substrate at the beginning of the measurements were at the level of sludge from conventional WWTPs and, thus, were significantly lower than in untreated wastewater. Since in the simulation of anaerobic treatment, the wastewater does not first pass through a WWTP in which part of the load is eliminated and only a small fraction is transferred to the sludge, it is possible that the removal rate is overestimated.

ARB. Anaerobic treatment inactivates some of the ARB in the digestion substrate [30,88-90]. The removal rate depends on the duration of treatment and the temperature in the reactor. The removal rate for $\mathrm{E}$. coli in a pure mesophilic system without disinfection at $70^{\circ} \mathrm{C}$ averages two to three logarithm steps over a 20- to 30-day period [91,92]. The UASB process is not optimized for pathogen removal and requires secondary treatment for achieving an effluent with a sufficient water quality. The UASB process was able to achieve a treatment efficiency of 1.09 logarithm steps or approximately $90 \%$ in the series of tests conducted by Espinosa et al. [93]. Of the surviving E. coli strains, the majority were measured in the sludge of the UASB reactor [93]. A removal rate of $95 \%$ is assumed for anaerobic treatment and, thus, a fraction of $5 \%$ that remains in the digestate. This estimation appears conservative and is also in agreement with Moerland et al. [94].

ARGs. According to Zhang et al. [95], anaerobic digester conditions may contribute to reducing ARGs in the digestion substrate. However, even here, resistance genes differ significantly in their characteristics. Thus, for certain resistance genes, a reduction of more than $90 \%$ might be achieved. However, measurements regarding other resistance genes, such as sul1, increased during thermophilic and during mesophilic treatments [95]. The total amount of genes present in the digestion substrate barely changed during the study described in [95], but there was a change in the ratio of various resistance genes. Sui et al. [96] described a reduction of ARGs ranging from 0.21 to 1.34 logarithm steps and an increase in concentrations for various resistance genes. No data for the UASB process itself 
could be identified in the literature. Therefore, also based on the previous considerations, a removal rate of $95 \%$ is assumed not only for ARB, but also for ARGs.

Table 4. Removal rates of antimicrobial resistances in the blanket digestion of upflow anaerobic sludge.

\begin{tabular}{cccc}
\hline Constituent Category & Removal Rates & Fraction into Effluent & Remark \\
\hline Antibiotics (ABs) & $75 \%$ & $25 \%$ & Assumption based on [86] \\
Antibiotic-resistant Bacteria (ARB) & $95 \%$ & $5 \%$ & Assumption based on [91-94] \\
Antibiotic Resistance Genes (ARGs) & $95 \%$ & $5 \%$ & Assumption based on [95,96] \\
\hline
\end{tabular}

\subsubsection{Disinfection of the Liquid Phase}

As already mentioned in Section 3.2.3, UASB processes require post-treatment of the liquid phase to achieve acceptable removal rates of bacteria [93]. This requirement is met through thermal disinfection. Table 5 describes the values applied in the simulations of this study.

Table 5. Removal rates of antimicrobial resistances in the disinfection of liquid phases.

\begin{tabular}{cccc}
\hline Constituent Category & Removal Rates & Fraction into Effluent & Remark \\
\hline Antibiotics (ABs) & $0 \%$ & $100 \%$ & no data found in literature \\
Antibiotic-resistant Bacteria (ARB) & $99.999 \%$ & 0.001 & no data found in literature \\
Antibiotic Resistance Genes (ARGs) & $99.999 \%$ & 0.001 & no data found in literature \\
\hline
\end{tabular}

ABs. In the simulation, it is assumed that thermal disinfection has no removal effect on the antibiotic constituent.

ARB. For the bacteria ESBL-E.Coli, a removal rate of thermal disinfection of five logarithm steps is assumed.

ARGs. As for the UASB process, there are no data on the removal rates of resistance genes in thermal disinfection. Therefore, the assumed value of five logarithm steps of ARB is also applied for ARGs.

\subsubsection{Advanced Oxidative Processes}

Advanced oxidative processes (AOPs) are applied in the source-separation-modified combined system for graywater treatment. Table 6 describes the values applied in the simulations of this study.

ABs. In a study on the removal characteristics of sulfamethoxazole, Dantas et al. [97] achieved a removal rate of approximately $90 \%$ with a $15 \mathrm{~min}$ ozonation at $0.4 \mathrm{~g}$ of ozone per liter.

ARB. In a study on the removal of ARB, Sousa et al. [98] determined a removal rate for enterobacteria of $99.98 \%( \pm 0.03)$ using a 15-minute ozonation (measurements of values for 15-minute ozonation were carried out with synthetic wastewater; longer ozonation resulted in improved degradation performance for synthetic wastewater (30 min and synthetic wastewater: $>99.999 \%$ removal rate; $30 \mathrm{~min}$ and real wastewater, 99.93\%)). Based on the measurements for the 15-minute ozonation and the comparative values for a 30-minute ozonation of real wastewater, a removal rate of $99.9 \%$ was specified for the simulation.

ARGs. Furthermore, in a study on the removal of ARB, Sousa et al. [98] found a removal rate for enterobacteria of $99.96 \%( \pm 0.01)$ using a 15 -minute ozonation. Again, the values were determined for a 15-minute ozonation with synthetic wastewater. The value for a 30-minute ozonation of real wastewater is $99.99 \%$. Hence, a purification efficiency of $99.9 \%$ is also assumed in the simulation for the ozonation of the resistance gene blaTEm. 
Table 6. Removal rates of antimicrobial resistances using advanced oxidative processes.

\begin{tabular}{ccccc}
\hline Constituent Category & Removal Rates & Fraction into Effluent & Remark & Literature \\
\hline Antibiotics (ABs) & $90 \%$ & $10 \%$ & & [97] \\
\hline $\begin{array}{c}\text { Antibiotic-resistant } \\
\text { Bacteria (ARB) }\end{array}$ & $99.9 \%$ & $0.1 \%$ & $\begin{array}{c}\text { Assumption: treatment } \\
\text { of real wastewater for } \\
\text { 15 min }\end{array}$ & $\begin{array}{c}\text { [98] } \\
\text { Antibiotic Resistance } \\
\text { Genes (ARGs) }\end{array}$ \\
\hline
\end{tabular}

\subsection{Specifics of Modeling Using SAmpSONS}

Some features of the case study could not be represented out of the box in SAmpSONS. The specifics of modeling CSOs, as well as disinfection, are therefore explained in the following.

CSOs. The case study shown in standard A 102 includes stormwater holding tank, stormwater with overflow, a stormwater tank retaining the first flush of stormwater, and a stormwater tank with overflow for settled combined sewage. Simulation of CSOs resulting from these structures is not provided by default for SAmpSONS. However, by using the mix and split blocks given in the SAmpSONS library, CSOs can be simulated approximately for a fixed time, such as one day or one year, respectively. For this purpose, the construction and discharge characteristics of the standard amendments [60] given in Table 10 are used as a reference. The input values required for the mix and split blocks are calculated using the annual discharged mixed water volume (Ve,MWÜ) (all formula symbols are taken from [59]) and the mixing ratio, $\mathrm{m}$ (Table 7). First, the proportions of wastewater (WW) and stormwater $(\mathrm{SW})$ in the discharged fraction are calculated via the mixing ratio $\mathrm{m}$. The ratio of WW and SW in the discharged volume is calculated thereafter. The representation of the CSO used in the simulation is simplified and distributes the discharged water evenly over the year. The occasionally occurring heavy rain events, which lead to an overload of the sewers and, thus, to discharges into surface waters, are not represented separately using SAmpSONS. This simplified representation results in deviations from the calculations in standard A 102, but the qualitative influence of the spillway structures, which has already been described (Figure 6), is also evident in the simulation.

Table 7. Sample calculation for split components spillway structure.

\begin{tabular}{cccccc}
\hline Structure & Ve,MWÜ & Ve,MWÜ & m & Fraction Wastewater & Fraction Stormwater \\
\hline & $\mathrm{m}^{3} / \mathrm{a}$ & $\mathrm{m}^{3} / \mathrm{d}$ & & $\mathrm{m}^{3} / \mathrm{d}$ & $\mathrm{m}^{3} / \mathrm{d}$ \\
$\mathrm{CSO} 1$ & 1744 & 4.7781 & 50 & 0.0956 & 4.6825 \\
\hline
\end{tabular}

For the source-separation-modified combined system, the discharge volume (Ve,MWÜ) was reduced because the separate blackwater discharge reduced the volume of wastewater flowing through the sewer. For this purpose, Ve,MWÜ was distributed on the days on which the combined sewage was discharged (ne). The now missing blackwater portion was subtracted from this. The reduced wastewater volume of a discharge day was multiplied again by the number of discharge days (ne) thereafter. The resulting reduced discharge volume (Ve,MWÜ) was then distributed over a year using the same method as in Table 7. The mixing ratio was retained in accordance with that of Table 10 for standard A 102 [59]. No wastewater from the industrial park (subarea 2) flowed into the stormwater overflow CSO1. The overflow was therefore modified in such a way that the stormwater not requiring treatment was completely discharged into the surface waters. All of these peculiarities are traceable in the SAmpSONS model files, which are attached as digital resources to this article. 


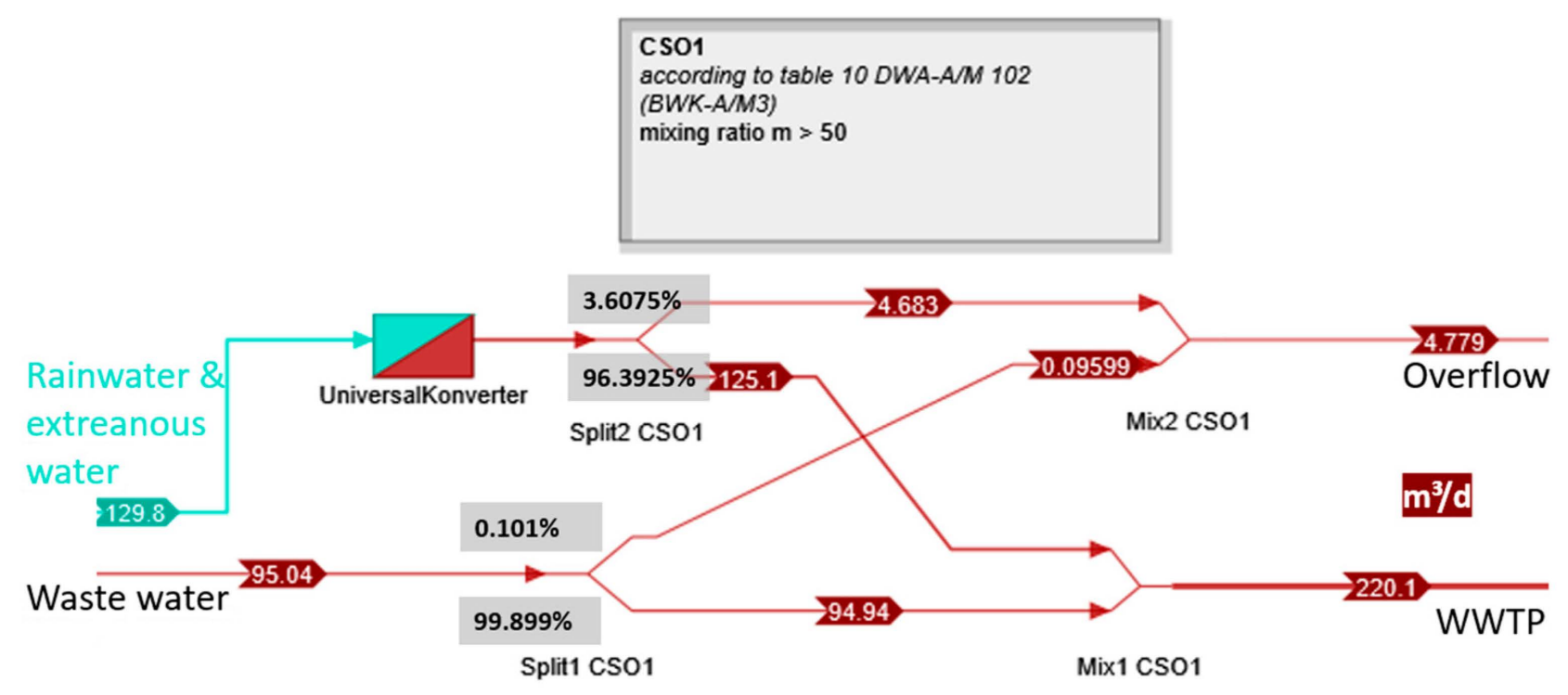

Figure 6. Modeling of the combined sewer overflow volumes in SAmpSONS.

Disinfection. For the blackwater treatment process described in Figure 4, not all process steps were available as blocks in SAmpSONS. For this reason, the UASB reactor, phosphate precipitation, deammonification, and thermal disinfection were simulated by the digestion, dewatering, and drying blocks from the SAmpSONS block library, with adapted parameters, such as removal rates. Since the digestion block does not output a stream of treated wastewater, the centrate generated in the dewatering and drying blocks was considered as treated wastewater. Possible removal rates that could result from phosphate precipitation and deammonification were neglected in this simulation. The effects of thermal disinfection were integrated into the dewatering and drying blocks.

\subsection{Simulation Results}

The simulation results (Table 8) indicate a substantial reduction of AMR emissions by the source-separation-modified combined system. The source-separation-modified combined system reduced ABs by $75.5 \%$ and ARB and ARGs by about eight logarithm steps each. In contrast, the separate system reduced ABs by $1.2 \%$ and ARB and ARGs by two-thirds.

The simulation results are available from the files provided as Supplementary Materials to this article. For each of the three sanitation system variants considered the following three files are attached: (1) the project file for SAmpSONS (extension: .simu, CaseStudy_CombSys.simu, CaseStudy_SepSys.simu, and CaseStu-dy_SourceSepCombSys. simu), (2) a graphical visualization of the modeled system (extension: png, Figures S1-S3), and (3) the simulation results (extension: .xlsx, Tables S1-S3). With the help of the configuration file and the freely downloadable simulation software SAmpSONS [58] it is furthermore for interested readers possible to carry out simulations with respect to the three variants. 
Table 8. Simulation results.

\begin{tabular}{cccc}
\hline & AB & ARB & ARG \\
\hline & $\begin{array}{c}\text { Sulfamethoxazole } \\
{[\mathrm{kg} / \mathrm{a}]}\end{array}$ & $\begin{array}{c}\text { ESBL-E.Coli } \\
{[\text { CFU /d] }}\end{array}$ & $\begin{array}{c}\text { blaTEM } \\
\text { [Cell Equivalent/d] }\end{array}$ \\
\hline Load Influent & 0.5475 & $9.5145 \times 10^{14}$ & $6.1431 \times 10^{14}$ \\
\hline Emission combined system & 0.2494 & $1.4112 \times 10^{13}$ & $9.1118 \times 10^{12}$ \\
\hline $\begin{array}{c}\text { Emission separate system } \\
\text { Emission source-separation-modified } \\
\text { combined system }\end{array}$ & 0.2464 & $4.7572 \times 10^{12}$ & $3.0715 \times 10^{12}$ \\
\hline Reduction combined vs. separate system & 0.0612 & $9.0764 \times 10^{4}$ & $5.8602 \times 10^{4}$ \\
\hline $\begin{array}{c}\text { Reduction combined vs. } \\
\text { source-separation-modified system }\end{array}$ & $1.2 \%$ & $66.3 \%$ & $66.3 \%$ \\
\hline
\end{tabular}

\section{Techno-Economic Challenges}

Source separation usually requires the separate discharge of material flows (e.g., graywater, blackwater, and urine). In the construction or renovation of buildings, graywater and blackwater might be discharged separately. Vacuum toilets and vacuum drainage systems might be used for the collection and discharge of blackwater. As mentioned above, solutions for existing buildings include a double inliner technology [52-54] and a housebased sensor-controlled wastewater switch $[55,56]$ to separate black- and graywater over time. For transformation from combined to separate systems or to the source-separation system that we favor, extensive re-routing of underground pipelines on properties and in street space is necessary [22]. Thus, a long-term transformation concept that includes economic feasibility must be formulated [99]. Economic feasibility needs to be evaluated against the backdrop of the enormous financial significance of the discharge of ARM into the aquatic environment, as outlined in the introduction. Trenchless installation of vacuum systems and installation in an existing combined sewer or as a double liner during sewer rehabilitation may significantly reduce costs compared to conventional rehabilitation solutions [43]. Based on a definition of a target sanitation system and a sewer rehabilitation strategy aligned with it, moving away from rehabilitation of small sections, implementation may proceed in a stepwise manner:

Step 1: Partial disconnection and management (storage and treatment) of stormwater and, thus, reduction of the proportion of wastewater in combined sewer overflows.

Step 2: Successive decoupling of blackwater in new and existing buildings with the new construction of pressure and/or vacuum systems for the discharge of blackwater and the use of existing buildings as a graywater mixing system.

Step 3: Conversion of existing and/or new construction of blackwater treatment plants with removal of micropollutants and AMR.

Parallel to this stepwise process, the identification and elimination of the misconnections in the separate system are required. In summary, such a reconstruction requires courage, time, and effort. The great current need for the rehabilitation of sewer systems might be perceived as an excellent window of opportunity to start a system change [43].

\section{Conclusions}

Antimicrobial resistance (AMR) is one of the most serious challenges we face in the future, causing - besides the emotional and ethical aspects of death and disease-immense economic burden. Current urban drainage promotes AMR. Pollution of surface waters by feces, the most significant input path of AMR, can be avoided if urban drainage material flows are no longer being mixed and purposeful treatments are implemented. The study described here used a simulation to demonstrate significant mitigation-i.e., a reduction of about six logarithm steps for antibiotic-resistant bacteria and for antibiotic resistance genes 
and a reduction of $75 \%$ for antibiotics - of AMR emissions into the aquatic environment with a sanitation system designed according to the principles of source separation ("sourceseparation-modified combined system"). The purposeful transformation of combined systems described here is thus by far one of the most effective measures for reducing AMR emissions. The limitations of the study include uncertain data from the literature, which was addressed with conservative estimations that likely render the results meaningful. Furthermore, the results are considered to be robust, since the major emission paths of UASB sludge and UASB centrate are largely eliminated through effective measures (incineration and disinfection). While the retrofitting of existing sanitation systems with the goal of mitigating AMR emissions appears to be time-consuming and costly, the currently huge demand for rehabilitation of sewer systems [24] should be regarded as a favorable chance-as a window of opportunity - to start retrofitting sanitation systems and, thus, effectively contribute to mitigating AMR emissions.

Supplementary Materials: The following are available online at https:/ / www.mdpi.com/article/10 $.3390 / w 13233342 / \mathrm{s} 1$. For each variant, three files are provided: The .simu file is the SAmpSONS project file, which is to be loaded with SAmpSONS; the .png file visualizes the variant as a schematic plan; the .xlsx file contains all results calculated by SAmpSONS. CaseStudy_CombSys.simu: SAmpSONS project file of the SUI equipped with combined systems. Figure S1: CaseStudy_CombSys, Table S1: CaseStudy_CombSys_Results, CaseStudy_SepSys.simu: SAmpSONS project file of the SUI equipped with separate systems. Figure S2: CaseStudy_SepSys, Table S2: CaseStudy_ SepSys_Results. CaseStudy_SourceSepCombSys.simu: SAmpSONS project file of the SUI equipped with source-separation-modified combined systems. Figure S3: CaseStudy_SourceSepCombSys, Table S3: CaseStudy_SourceSepCombSys_Results.

Author Contributions: Conceptualization, J.L. and M.B.; methodology, J.L. and M.B.; software, M.B. and H.S.; validation, J.L. and M.B.; formal analysis, J.L.; investigation, J.L. and M.B.; writing—original draft preparation, J.L., H.S. and M.B.; writing-review and editing, J.L., H.S. and M.B.; supervision, J.L.; project administration, J.L.; funding acquisition, J.L. All authors have read and agreed to the published version of the manuscript.

Funding: We acknowledge support from the German Research Foundation (DFG) and BauhausUniversität Weimar within the program of Open Access Publishing. Further, we would like to acknowledge the support of the German Federal Environmental Foundation (DBU) through grants 32768 and 35081.

Conflicts of Interest: The authors declare no conflict of interest.

\section{References}

1. World Health Organization. Antimicrobial Resistance. Available online: https://www.who.int/news-room/fact-sheets/detail/ antimicrobial-resistance (accessed on 23 May 2021).

2. Czekalski, N.; von Gunten, U.; Bürgmann, H. Antibiotikaresistenzen im Wasserkreislauf. Aqua Gas 2016, 9, 72-80.

3. Bush, K.; Courvalin, P.; Dantas, G.; Davies, J.; Eisenstein, B.; Huovinen, P.; Jacoby, G.A.; Kishony, R.; Kreiswirth, B.N.; Kutter, E.; et al. Tackling antibiotic resistance. Nat. Rev. Microbiol. 2011, 9, 894-896. [CrossRef]

4. Berendonk, T.U.; Manaia, C.M.; Merlin, C.; Fatta-Kassinos, D.; Cytryn, E.; Walsh, F.; Bürgmann, H.; Sørum, H.; Norström, M.; Pons, M.N.; et al. Tackling antibiotic resistance: The environmental framework. Nat. Rev. Microbiol. 2015, 13, 310-317. [CrossRef]

5. Clatworthy, A.E.; Pierson, E.; Hung, D.T. Targeting virulence: A new paradigm for antimicrobial therapy. Nat. Chem. Biol. 2007, 3, 541-548. [CrossRef] [PubMed]

6. Buergmann, H.; Czekalski, N.; Bryner, A. Verbreitung Von Antibiotikaresistenzen Im Wasser. Available online: https://www. eawag.ch/fileadmin/Domain1/Beratung/Beratung_Wissenstransfer/Publ_Praxis/Faktenblaetter/fb_antibiotikaresistenzen_ juli15.pdf (accessed on 2 July 2021).

7. Taylor, J.; Hafner, M.; Yerushalmi, E.; Smith, R.; Bellasio, J.; Vardavas, R.; Bienkowska-Gibbs, T.; Rubin, J. Estimating the Economic Costs of Antimicrobial Resistance: Model and Results; RAND Corporation: Cambridge, UK, 2014.

8. Firk, J.; Schleiffer, P.; Pinnekamp, J. Einträge von Antibiotikaresistenzen in Gewässer und Bewertung von Möglichkeiten zur Eintragsminderung. In Proceedings of the 53. Essener Tagung Für Wasserwirtschaft, Essen, Germany, 18-20 March 2020; Gesellschaft Zur Förderung Der Siedlungswasserwirtschaft An Der RWTH Aachen E.V.: Aachen, Germany, 2020; pp. 45/1-45/12.

9. Gullberg, E.; Cao, S.; Berg, O.G.; Ilbäck, C.; Sandegren, L.; Hughes, D.; Andersson, D.I. Selection of resistant bacteria at very low antibiotic concentrations. PLoS Pathog. 2011, 7, e1002158. [CrossRef] 
10. Chow, L.; Waldron, L.; Gillings, M.R. Potential impacts of aquatic pollutants: Sub-clinical antibiotic concentrations induce genome changes and promote antibiotic resistance. Front. Microbiol. 2015, 6, 803. [CrossRef] [PubMed]

11. Stoll, C.; Sidhu, J.P.S.; Tiehm, A.; Toze, S. Prevalence of clinically relevant antibiotic resistance genes in surface water samples collected from Germany and Australia. Environ. Sci. Technol. 2012, 46, 9716-9726. [CrossRef] [PubMed]

12. Yang, J.F.; Ying, G.G.; Liu, S.; Zhou, L.J.; Zhao, J.L.; Tao, R.; Peng, P.A. Biological degradation and microbial function effect of norfloxacin in a soil under different conditions. J. Environ. Sci. Health Part B Pestic. Food Contam. Agric. Wastes 2012, 47, $288-295$. [CrossRef] [PubMed]

13. Pinnekamp, J.; Firk, J.; Keysers, C.; Mousel, D.; Ruppelt, J.; Tondera, K. Elimination von Mikroschadstoffen, Mikroplastik, und antibiotikaresistenten Keimen. In Proceedings of the Bochumer Workshop 8, Bochum, Germany, 6-7 September 2016. Available online: https:/ / docplayer.org/73494442-Elimination-von-mikroschadstoffen-mikroplastik-antibiotikaresistenten-keimen.html (accessed on 25 October 2021).

14. Guo, J.; Li, J.; Chen, H.; Bond, P.L.; Yuan, Z. Metagenomic analysis reveals wastewater treatment plants as hotspots of antibiotic resistance genes and mobile genetic elements. Water Res. 2017, 123, 468-478. [CrossRef] [PubMed]

15. Schmitt, H.; Blaak, H.; Kemper, M.; van Passel, M.; Hierink, F.; van Leuken, J.; De Roda Husman, A.M.; van der Grinten, E.; Rutgers, M.; Schijven, R.; et al. Bronnen Va Antibioticaresistentie in Het Milieu En Mogelijke Maatregelen; Rijksinstituut voor Volksgezondheid en Milieu RIVM: Bilthoven, The Netherlands, 2017. [CrossRef]

16. Graham, D.W.; Bergeron, G.; Bourassa, M.W.; Dickson, J.; Gomes, F.; Howe, A.; Kahn, L.H.; Morley, P.S.; Scott, H.M.; Simjee, S.; et al. Complexities in understanding antimicrobial resistance across domesticated animal, human, and environmental systems. Ann. N. Y. Acad. Sci. 2019, 1441, 17-30. [CrossRef]

17. Pinnekamp, J.; Firk, J.; Schleiffer, P. Bewertung der urbanen Gewässereinträge und Möglichkeiten der Eintragsminderung. In Proceedings of the Abschlussveranstaltung Des BMBF-Forschungsvorhabens Zu Antibiotikaresistenzen Im Wasserkreislauf (HyReKA), Eggenstein-Leopoldshafen, Germany, 3-4 April 2019.

18. Mannina, G.; Viviani, G. Separate and combined sewer systems: A long-term modelling approach. Water Sci. Technol. 2009, 60, 555-565. [CrossRef] [PubMed]

19. Dettmar, J.; Brombach, H. Im Spiegel der Statistik: Abwasserkanalisation und Regenwasserbehandlung in Deutschland. Korresp. Abwasser Abfall 2019, 66, 354-364.

20. Botturi, A.; Ozbayram, E.G.; Tondera, K.; Gilbert, N.I.; Rouault, P.; Caradot, N.; Gutierrez, O.; Daneshgar, S.; Frison, N.; Akyol, Ç.; et al. Combined sewer overflows: A critical review on best practice and innovative solutions to mitigate impacts on environment and human health. Crit. Rev. Environ. Sci. Technol. 2021, 51, 1585-1618. [CrossRef]

21. Phillips, P.J.; Chalmers, A.T.; Gray, J.L.; Kolpin, D.W.; Foreman, W.T.; Wall, G.R. Combined sewer overflows: An environmental source of hormones and wastewater micropollutants. Environ. Sci. Technol. 2012, 46, 5336-5343. [CrossRef] [PubMed]

22. Schmitt, T.G. Mischwasserkanalisation 2021-Quo Vadis? KA Korresp. Abwasser Abfall 2021, 68, 430-439.

23. Petrie, B. A review of combined sewer overflows as a source of wastewater-derived emerging contaminants in the environment and their management. Environ. Sci. Pollut. Res. 2021, 32095-32110. [CrossRef]

24. Berger, C.; Falk, C.; Hetzel, F.; Pinnekamp, J.; Ruppelt, J.; Schleiffer, P.; Schmitt, J. Zustand der Kanalisation in Deutschland: Ergebnisse der DWA-Umfrage 2020. KA Korresp. Abwasser Abfall 2020, 67, 939-953. [CrossRef]

25. Nickel, J.P.; Fuchs, S. Micropollutant emissions from combined sewer overflows. Water Sci. Technol. 2019, 80, 2179-2190. [CrossRef] [PubMed]

26. Gasperi, J.; Garnaud, S.; Rocher, V.; Moilleron, R. Priority pollutants in wastewater and combined sewer overflow. Sci. Total Environ. 2008, 407, 263-272. [CrossRef]

27. Gasperi, J.; Cladière, M.; Rocher, V.; Moilleron, R. Combined sewer overflow quality and EU Water Framework Directive. Urban Waters 2009, 1, 124-128.

28. Weyrauch, P.; Matzinger, A.; Pawlowsky-Reusing, E.; Plume, S.; von Seggern, D.; Heinzmann, B.; Schroeder, K.; Rouault, P. Contribution of combined sewer overflows to trace contaminant loads in urban streams. Water Res. 2010, 44, 4451-4462. [CrossRef] [PubMed]

29. Dris, R.; Gasperi, J.; Rocher, V.; Saad, M.; Renault, N.; Tassin, B. Microplastic contamination in an urban area: A case study in Greater Paris. Environ. Chem. 2015, 12, 592-599. [CrossRef]

30. DECHEMA Gesellschaft für Chemische Technik und Biotechnologie. Risikomanagement Von Neuen Schadstoffen Und Krankheitserregern Im Wasserkreislauf Praxishandbuch; DECHEMA Gesellschaft für Chemische Technik und Biotechnologie, Ed.; DECHEMA, Gesellschaft für Chemische Technik und Biotechnologie: Frankfurt am Main, Germany, 2016.

31. Kay, P.; Hughes, S.R.; Ault, J.R.; Ashcroft, A.E.; Brown, L.E. Widespread, routine occurrence of pharmaceuticals in sewage effluent, combined sewer overflows and receiving waters. Environ. Pollut. 2017, 220, 1447-1455. [CrossRef]

32. Munro, K.; Martins, C.P.B.; Loewenthal, M.; Comber, S.; Cowan, D.A.; Pereira, L.; Barron, L.P. Evaluation of combined sewer overflow impacts on short-term pharmaceutical and illicit drug occurrence in a heavily urbanised tidal river catchment (London, UK). Sci. Total Environ. 2019, 657, 1099-1111. [CrossRef]

33. Brunsch, A.F.; Zubieta Florez, P.; Langenhoff, A.A.M.; ter Laak, T.L.; Rijnaarts, H.H.M. Retention soil filters for the treatment of sewage treatment plant effluent and combined sewer overflow. Sci. Total Environ. 2020, 699, 134426. [CrossRef]

34. Mutzner, L.; Bohren, C.; Mangold, S.; Bloem, S.; Ort, C. Spatial Differences among Micropollutants in Sewer Overflows: A Multisite Analysis Using Passive Samplers. Environ. Sci. Technol. 2020, 54, 6584-6593. [CrossRef] 
35. Young, S.; Juhl, A.; O'Mullan, G.D. Antibiotic-resistant bacteria in the Hudson River Estuary linked to wet weather sewage contamination. J. Water Health 2013, 11, 297-310. [CrossRef]

36. Eramo, A.; Reyes, H.D.; Fahrenfeld, N.L. Partitioning of antibiotic resistance genes and fecal indicators varies intra and inter-storm during combined sewer overflows. Front. Microbiol. 2017, 8, 2024. [CrossRef]

37. Quach-Cu, J.; Herrera-Lynch, B.; Marciniak, C.; Adams, S.; Simmerman, A.; Reinke, R.A. The effect of primary, secondary, and tertiary wastewater treatment processes on antibiotic resistance gene (ARG) concentrations in solid and dissolved wastewater fractions. Water 2018, 10, 37. [CrossRef]

38. Exner, M.; Schmithausen, R. Verbundvorhaben HyReKA: Hintergrund, Zielsetzung, Methoden. In Proceedings of the Abschlussveranstaltung Des BMBF-Forschungsvorhabens Zu Antibiotikaresistenzen Im Wasserkreislauf (HyReKA), EggensteinLeopoldshafen, Germany, 3-4 April 2019.

39. Jäger, T.; Hembach, N.; Elpers, C.; Wieland, A.; Alexander, J.; Hiller, C.; Krauter, G.; Schwartz, T. Reduction of Antibiotic Resistant Bacteria During Conventional and Advanced Wastewater Treatment, and the Disseminated Loads Released to the Environment. Front. Microbiol. 2018, 9, 2599. [CrossRef]

40. Hembach, N.; Alexander, J.; Wieland, A.; Hiller, C.X.; Schwartz, T. Untersuchung der Eliminationsleistung verschiedener weiterführender Abwasserreinigungsverfahren zur Keimreduktion. Vom Wasser Das J. 2018, 2, 65-68.

41. Hiller, C.X.; Hübner, U.; Fajnorova, S.; Schwartz, T.; Drewes, J.E. Antibiotic microbial resistance (AMR) removal efficiencies by conventional and advanced wastewater treatment processes: A review. Sci. Total Environ. 2019, 685, 596-608. [CrossRef]

42. Mousel, D.; Bastian, D.; Firk, J.; Palmowski, L.; Pinnekamp, J. Removal of pharmaceuticals from wastewater of health care facilities. Sci. Total Environ. 2021, 751, 141310. [CrossRef]

43. Londong, J. HOSS: Ein Hygiene-orientiertes Siedlungsentwässerungssystem. KA Korresp. Abwasser Abfall 2022. submitted.

44. Schütze, M.; Wriege-Bechtold, A.; Zinati, T.; Söbke, H.; Wißmann, I.; Schulz, M.; Veser, S.; Londong, J.; Barjenbruch, M.; Alex, J. Simulation and visualization of material flows in sanitation systems for streamlined sustainability assessment. Water Sci. Technol. 2019, 79, 1966-1976. [CrossRef]

45. Zinati, T.; Wriege-Bechtold, A.; Barjenbruch, M.; Schütze, M.; Schulz, M.; Kraus, M.; Wissmann, I.; Veser, S.; Söbke, H.; Londong, J. SAmpSONS: Softwarewerkzeug zur vergleichenden Vorplanung von Abwasserinfrastrukturen. KA Korresp. Abwasser Abfall. 2021, 68, 1-7. [CrossRef]

46. Londong, J. Strategien für die Siedlungsentwässerung. KA Korresp. Abwasser Abfall 2000, 47, 1434-1444.

47. Larsen, T.A.; Udert, K.M.; Lienert, J. Source Separation and Decentralization for Wastewater Management; IWA Publishing: London, UK, 2013; ISBN 9781780401072.

48. Londong, J. Practical experiences with source separation in Germany. In Source Separation and Decentralization for Wastewater Management; Larsen, T.A., Udert, K.M., Lienert, J., Eds.; IWA Publishing: London, UK, 2013; pp. 423-430.

49. DWA. Neuartige Sanitärsysteme (NASS); Themenband des DWA-Fachausschusses KA 1 und Seiner 6 Arbeitsgruppen: Hennef, Germany, 2008.

50. Gao, M.; Zhang, L.; Florentino, A.P.; Liu, Y. Performance of anaerobic treatment of blackwater collected from different toilet flushing systems: Can we achieve both energy recovery and water conservation? J. Hazard. Mater. 2019, 365, 44-52. [CrossRef]

51. Londong, J.; Wätzel, T.; Giese, T. Combining the production of renewable energy with innovative urban drainage systems-The KREIS Project. In Proceedings of the 13th IWA Specialized Conference on Small Water and Wastewater Systems \& 5th IWA Specialized Conference on Resources-Oriented Sanitation, Athens, Greece, 14-16 September 2016.

52. Veser, S. Intelligent infrastructure systems for urban wastewater management. Research project EvaSENS. Bluefacts. Int. J. Water-Manag. 2012, 2012, 110-114.

53. Veser, S. Doppel-Inliner-Verfahren Zur Getrennten Erfassung Von Schwarz-Und Grauwasser Im Gebäudebestand. Ph.D. Dissertation, Bauhaus-Universität Weimar, Weimar, Germany, 2015.

54. Veser, S.; Berndt, M. EVaSENS-Neue Wege der Abwassertrennung im Siedlungsbestand. Wasser Und Abfall 2014, 16, 32-37. [CrossRef]

55. Hörnlein, S.; Londong, J.; Veser, S.; Berndt, M. Technische Lösungen für Source Separation im Bestand. 2021; in preparation.

56. Hörnlein, S. A Modelling Approach for Time-Sequential Source Separation of Domestic Wastewaters. 2022; manuscript in preparation.

57. Gujer, W. Siedlungswasserwirtschaft, 3rd ed.; Springer: Berlin/Heidelberg, Germany, 2007.

58. ifak e.V. SAmpSONS-Visualisation and Sustainability Assessment of Resource-Orientated Sanitation Systems. Available online: https:/ / www.ifak.eu/en/products/sampsons (accessed on 25 October 2021).

59. DWA. Arbeitsblatt DWA-A 102-2/BWK-A 3-2-Grundsätze Zur Bewirtschaftung Und Behandlung Von Regenwetterabflüssen Zur Einleitung in Oberflächengewässer-Teil 2: Emissionsbezogene Bewertungen Und Regelungen; DWA: Hennef, Germany, 2020.

60. DWA-Arbeitsgruppe ES-2.1. Systembezogene Anforderungen und Grundsätze. Arbeits—Und Merkblattreihe DWA-A/M 102 (BWK-A/M 3) Zusatzdatei: Anwendungsbeispiele; DWA: Hennef, Germany, 2020; Volume 102.

61. Firk, J. (RWTH Aachen University, Aachen, Germany). Personal communication, 2021. 
62. Exner, M.; Schmithausen, R. Synthese Und Abschlussbericht HyReKA. Hygienisch-Medizinische Relevanz Und Kontrolle Antibiotika-Resistenter Krankheitserreger in Klinischen, Landwirtschaftlichen Und Kommunalen Abwässern Und Deren Bedeutung in Rohwässern; Bonn/Karlsruhe/Dresden/Aachen/Bad Elster, Germany. 2020. Available online: https: / / docplayer. org/199750169-Hyreka-synthese-und-abschlussbericht-bonn-karlsruhe-dresden-aachen-bad-elster-2020.html (accessed on 24 November 2021).

63. Rau, W.; Metzger, S. Bestandsaufnahme Der Spurenstoffsituation Von Kläranlagen in Baden-Württemberg; Kompetenzzentrum Spurenstoffe BW: Stuttgart, Germany, 2017; Available online: https://koms-bw.de/cms/content/media/BAn_Bericht-Teil1_veroeffentl_ final.pdf (accessed on 24 November 2021).

64. Wellbrock, K.; Knobloch, J.K.-W.; Heim, M.; Grottker, M. Spurenstoffe Und Multiresistente Bakterien in Den Entwässerungssystemen Schleswig-Holsteins. Kiel/Lübeck/Hamburg, Germany. 2019. Available online: https://www.th-luebeck.de/fileadmin/ media/01_Hochschule/05_Fachbereiche/Bauwesen/Bilder/Projekte/PrioSH/Zusammenfassung_und_Ausblick.pdf (accessed on 24 November 2021).

65. Forth, W.; Henschler, D.; Rummel, W. Allgemeine Und Spezielle Pharmakologie Und Toxikologie; 8. Auflage; Urban \& Fischer München: Jena, Germany, 2001.

66. Feldmann, D.F. Modellberechnungen Zum Verhalten Und Verbleib Von Arzneimittelrückständen Im Krankenhausabwasser Und Beurteilungs-Möglichkeiten Ihres Ökotoxikologischen Gefährdungspotentials; Technische Universität Berlin: Berlin, Germany, 2005.

67. Alexander, J.; Hembach, N.; Schwartz, T. Evaluation of antibiotic resistance dissemination by wastewater treatment plant effluents with different catchment areas in Germany. Sci. Rep. 2020, 10, 8952. [CrossRef]

68. Alexander, J. Mikrobiologische Charakterisierung Von Anthropogen Beeinflussten Wassersystemen Und Evaluierung Von Abwasserbehandlungsverfahren; Karlsruher Institut für Technologie (KIT): Karlsruhe, Germany, 2017.

69. Fatta-Kassinos, D.; Meric, S.; Nikolaou, A. Pharmaceutical residues in environmental waters and wastewater: Current state of knowledge and future research. Anal. Bioanal. Chem. 2011, 399, 251-275. [CrossRef]

70. Gracia-Lor, E.; Sancho, J.V.; Serrano, R.; Hernández, F. Occurrence and removal of pharmaceuticals in wastewater treatment plants at the Spanish Mediterranean area of Valencia. Chemosphere 2012, 87, 453-462. [CrossRef]

71. Narumiya, M.; Nakada, N.; Yamashita, N.; Tanaka, H. Phase distribution and removal of pharmaceuticals and personal care products during anaerobic sludge digestion. J. Hazard. Mater. 2013, 260, 305-312. [CrossRef]

72. Koschorreck, J. Arzneimittel in Der Umwelt: Zu Risiken Und Nebenwirkungen Fragen Sie Das Umweltbundesamt; Federal Environment Agency: Dessau, Germany, 2005.

73. Hörsing, M.; Ledin, A.; Grabic, R.; Fick, J.; Tysklind, M.; la Cour Jansen, J.; Andersen, H.R. Determination of sorption of seventy-five pharmaceuticals in sewage sludge. Water Res. 2011, 45, 4470-4482. [CrossRef]

74. Verlicchi, P.; Galletti, A.; Petrovic, M.; Barceló, D.; Al Aukidy, M.; Zambello, E. Removal of selected pharmaceuticals from domestic wastewater in an activated sludge system followed by a horizontal subsurface flow bed-Analysis of their respective contributions. Sci. Total Environ. 2013, 454-455, 411-425. [CrossRef]

75. Göbel, A.; McArdell, C.S.; Joss, A.; Siegrist, H.; Giger, W. Fate of sulfonamides, macrolides, and trimethoprim in different wastewater treatment technologies. Sci. Total Environ. 2007, 372, 361-371. [CrossRef]

76. Suárez, S.; Ramil, M.; Omil, F.; Lema, J.M. Removal of pharmaceutically active compounds in nitrifying-denitrifying plants. Water Sci. Technol. 2005, 52, 9-14. [CrossRef]

77. Radjenović, J.; Petrović, M.; Barceló, D. Fate and distribution of pharmaceuticals in wastewater and sewage sludge of the conventional activated sludge (CAS) and advanced membrane bioreactor (MBR) treatment. Water Res. 2009, 43, 831-841. [CrossRef]

78. Fanck, B.; Heberer, T. Multi Method for the Detection of Antibiotic Residues in Various Waters Using Solid-Phase Extraction and Liquid Chromatography/Mass Spectrometry. 2005; manuscript.

79. DWA-Fachausschuss KA-8 Antibiotika und antibiotikaresistente Bakterien und Gene im Wasserkreislauf. KA Korresp. Abwasser Abfall 2018, 65, 545-550. [CrossRef]

80. Kistemann, T.; Rind, E.; Rechenburg, A.; Koch, C.; Claßen, T.; Herbst, S.; Wienand, I.; Exner, M. A comparison of efficiencies of microbiological pollution removal in six sewage treatment plants with different treatment systems. Int. J. Hyg. Environ. Health 2008, 211, 534-545. [CrossRef]

81. Güde, H.; Eckenfels, S.; Palmer, A.; Fitz, S.; Pietruske, J.; McTaggart, K.; Haibel, B.; Setzer, T. Erfassung Und Bewertung Von Eintragswegen Für Belastungen Mit Fäkalkeimen Im Einzugsgebiet Der Seefelder Aach (Bodenseekreis); Langenargen, Germany, 2001. Available online: https://pudi.lubw.de/detailseite/-/publication/45442-Erfassung_und_Bewertung_von_Eintragswegen_f\% C3\%BCr_Belastungen_mit_F\%C3\%A4kalkeimen_im_Einzugsgebiet_der_Seefe.pdf (accessed on 5 May 2001).

82. Mascher, F.; Karl, F.; Folli, B.; Kittinger, C.; Lipp, M.; Mascher, W.; Pfeifer, B.; Platzer, S.; Schmutz, R.; Schwaiger, M. Die Reiningungsleistung Einer Kommunalen Abwasserreinigungsanlage Im Hinblick Auf Bakterielle Fäkalindikatoren Und Die Auswirkungen Auf Den Vorfluter; Graz, Austria, 2014. Available online: http:/ / docplayer.org/74428142-Endbericht-zum-projekt-a.html (accessed on 25 October 2021).

83. Feuerpfeil, I.; López-Pila, J.; Schmidt, R.; Schneider, E.; Szewzyk, R. Antibiotikaresistente Bakterien und Antibiotika in der Umwelt. Bundesgesundheitsblatt Gesundheitsforsch. Gesundh. 1999, 42, 37-50. [CrossRef] 
84. Adler, N.; Balzer, F.; Blondzik, K.; Brauer, F.; Chorus, I.; Ebert, I.; Fiedler, T.; Grummt, T.; Heidemeier, J.; Hein, A. Antibiotika Und Antibiotikaresistenzen in Der Umwelt: Hintergrund, Herausforderungen Und Handlungsoptionen; Umweltbundesamt: Dessau, Germany, 2018.

85. Pallares-Vega, R.; Blaak, H.; van der Plaats, R.; de Roda Husman, A.M.; Hernandez Leal, L.; van Loosdrecht, M.C.M.; Weissbrodt, D.G.; Schmitt, H. Determinants of presence and removal of antibiotic resistance genes during WWTP treatment: A cross-sectional study. Water Res. 2019, 161, 319-328. [CrossRef] [PubMed]

86. Hou, J.; Chen, Z.; Gao, J.; Xie, Y.; Li, L.; Qin, S.; Wang, Q.; Mao, D.; Luo, Y. Simultaneous removal of antibiotics and antibiotic resistance genes from pharmaceutical wastewater using the combinations of up-flow anaerobic sludge bed, anoxic-oxic tank, and advanced oxidation technologies. Water Res. 2019, 159, 511-520. [CrossRef] [PubMed]

87. Carballa, M.; Omil, F.; Ternes, T.; Lema, J.M. Fate of pharmaceutical and personal care products (PPCPs) during anaerobic digestion of sewage sludge. Water Res. 2007, 41, 2139-2150. [CrossRef]

88. Galler, H.; Zarfel, G.; Feierl, G.; Haas, D.; Leitner, E.; Melkes, A.; Posch, J.; Reinthaler, F.F.; Winter, I. Nachweis Antibiotikaresistenter Escherichia Coli-Stämme Aus Klärschlamm Unter Berücksichtigung Der Verschiedenen Klärschlammbehandlungsverfahren; Abfall-und Ressourcenwirtschaft: Graz, Austria, 2010.

89. Glaeser, S.; Schauss, T.; Dott, W.; Kämpfer, P. Biogasanlagen—Quelle oder Senke für Antibiotika-resistente Bakterien? BIOspektrum 2016, 22, 656-658. [CrossRef]

90. Saunders, O.; Harrison, J.; Fortuna, A.M.; Whitefield, E.; Bary, A. Effect of anaerobic digestion and application method on the presence and survivability of E. coli and fecal coliforms in dairy waste applied to soil. Water Air Soil Pollut. 2012, 223, 1055-1063. [CrossRef]

91. Smith, S.R.; Lang, N.L.; Cheung, K.H.M.; Spanoudaki, K. Factors controlling pathogen destruction during anaerobic digestion of biowastes. Waste Manag. 2005, 25, 417-425. [CrossRef] [PubMed]

92. Avery, L.M.; Anchang, K.Y.; Tumwesige, V.; Strachan, N.; Goude, P.J. Potential for Pathogen reduction in anaerobic digestion and biogas generation in Sub-Saharan Africa. Biomass Bioenergy 2014, 70, 112-124. [CrossRef]

93. Espinosa, M.F.; Verbyla, M.E.; Vassalle, L.; Rosa-Machado, A.T.; Zhao, F.; Gaunin, A.; Mota, C.R. Reduction and partitioning of viral and bacterial indicators in a UASB reactor followed by high rate algal ponds treating domestic sewage. Sci. Total Environ. 2021, 760, 144309. [CrossRef]

94. Moerland, M.J.; Borneman, A.; Chatzopoulos, P.; Fraile, A.G.; van Eekert, M.H.A.; Zeeman, G.; Buisman, C.J.N. Increased (Antibiotic-resistant) pathogen indicator organism removal during (hyper)thermophilic anaerobic digestion of concentrated black water for safe nutrient recovery. Sustainability 2020, 12, 9336. [CrossRef]

95. Zhang, T.; Yang, Y.; Pruden, A. Effect of temperature on removal of antibiotic resistance genes by anaerobic digestion of activated sludge revealed by metagenomic approach. Appl. Microbiol. Biotechnol. 2015, 99, 7771-7779. [CrossRef] [PubMed]

96. Sui, Q.; Zhang, J.; Chen, M.; Tong, J.; Wang, R.; Wei, Y. Distribution of antibiotic resistance genes (ARGs) in anaerobic digestion and land application of swine wastewater. Environ. Pollut. 2016, 213, 751-759. [CrossRef] [PubMed]

97. Dantas, R.F.; Contreras, S.; Sans, C.; Esplugas, S. Sulfamethoxazole abatement by means of ozonation. J. Hazard. Mater. 2008, 150, 790-794. [CrossRef]

98. Sousa, J.M.; Macedo, G.; Pedrosa, M.; Becerra-Castro, C.; Castro-Silva, S.; Pereira, M.F.R.; Silva, A.M.T.; Nunes, O.C.; Manaia, C.M. Ozonation and UV254nm radiation for the removal of microorganisms and antibiotic resistance genes from urban wastewater. $J$. Hazard. Mater. 2017, 323, 434-441. [CrossRef] [PubMed]

99. Maier, K.; Söbke, H.; Londong, J. Principles of Transition Paths: Purposeful Conversion of Water Infrastructure Systems to Multi Stream Variants. In Proceedings of the Water Efficiency Conference 2015, Exeter, UK, 5-7 August 2015; Memon, F.A., Ed.; WATEF Network/University of Brighton: Exeter, UK, 2015; pp. 359-368. 